\title{
INFLUENCE OF BLEACHED SOFTWOOD AND HARDWOOD KRAFT PULPS ON TISSUE PAPER PROPERTIES
}

\author{
MÁRIA FIŠEROVÁ, JURAJ GIGAC, MONIKA STANKOVSKÁ and ELENA OPÁLENÁ \\ Pulp and Paper Research Institute, Dúbravská cesta 14, 84104 Bratislava, Slovak Republic \\ ๔Corresponding author: Mária Fišerová, fiserova@vupc.sk
}

Received February 26, 2019

\begin{abstract}
The properties of bleached softwood and hardwood kraft pulps at different drainage resistance were compared. Bleached softwood kraft pulps required twice as long time as bleached hardwood kraft pulps, in laboratory beating, to achieve the same drainage resistance. The softwood pulp from a mixture of pine and spruce had the highest dry and wet tensile strength, which was slightly lower than the tensile strength of the pine pulp. The birch pulps had higher dry and wet tensile strength than the pulps from eucalyptus and beech. The bleached softwood kraft pulps had higher fibre strength and fibre length than the hardwood kraft pulps, whose fibres had a higher fibre bonding ability. The water absorption and bulk softness of the bleached hardwood kraft pulps were higher in comparison with those of softwood kraft pulps. The highest water absorption had the bleached kraft pulps from eucalyptus and beech, while the pulps from birch had the highest bulk softness. The bleached hardwood kraft pulps with high bulk softness were characterized by low optical surface variability, while the softwood pulps with low bulk softness had high optical surface variability. Among the tested bleached kraft pulps, the birch and beech pulps had higher brightness than the pulps from eucalyptus, pine and the mixture of pine and spruce. Pulp beating increases the tensile strength, while reducing the water absorption, bulk softness and brightness. Therefore, it is recommended to beat the pulp for tissue paper production to achieve only low drainage resistance, which depends on the type of tissue paper products.
\end{abstract}

Keywords: bleached kraft pulp, beatability, tensile strength, fibre characteristics, water absorption, bulk softness, optical properties

\section{INTRODUCTION}

The production and consumption of tissue papers is constantly increasing, and this trend is also expected during the next years. According to CEPI (Central European Paper Industries) statistics, in the last 10 years, the production of tissue paper in Europe has increased by an average of $1.7 \%$ per year and the consumption of tissue paper by $1.4 \%$. The share of tissue paper production in Europe represents $7.9 \%$ of the total amount of produced paper.

Tissue paper is mostly characterized by high bulk and good absorbent properties. These properties are most widely seen in common toilet papers, paper towels, and hygiene products. Tissue paper is generally made from virgin pulp and/or recycled pulp. The best quality products from tissue paper are still mainly produced from virgin pulp, usually with a combination of long fibre softwood and short fibre hardwood pulp. The fibre type that can be used depends on the end product. Virgin pulps are bleached to increase the brightness, but it may enhance the absorption properties of the end product.

The most common virgin pulp is kraft pulp, but sulphite and chemi-thermomechanical pulps are also used. The latter is mostly used to give the paper more bulk. Softwood pulps are usually made from spruce or pine, while hardwood pulps - from birch, eucalyptus, aspen or beech wood. ${ }^{1}$ From a morphological perspective, there are many similarities between the hardwoods, but the fibres from various wood species are different in their fibre structure, chemical composition and the tendency to collapse. The selection of a fibre type for tissue paper depends on the final product.

Virgin pulps are often subjected to moderate beating to increase the tensile properties of the final product. The beating energy consumption is normally lower than in conventional papermaking, since it is desirable to preserve the bulk, water absorption and softness. The way pulps respond to beating is also affected by the 
pulp yield. The shortening of fibres will give an improved formation. During pulp beating, fibrillation of the fibre surface occurs and the outer layer of the fibres may be damaged. The surface of the fibres increases and more options for bonds between fibres are created. The increase of fibre bonds will lead to lower porosity and therefore will increase the density of paper and decrease the light scattering coefficient. Fibre beating increases the bonding strength not only by a larger surface of fibrillated fibres, but also through more flexible fibres. The amount of fines increases with increasing beating, but gets stabilized to a constant level. ${ }^{2}$ When the pulp is beaten, the dewatering of the web will be deteriorated and therefore the dewatering capacity will limit the beating. In the future, the refiner systems will treat fibres individually and hopefully there will be a possibility of chemical, biological or sonic treatments, instead of mechanical treatment.

The fibrous material is the item of a finished tissue paper product with the highest cost; it typically represents more than $50 \%$ of the total cost, of course, with variations and depending on quality attributes, such as softness, bulk, strength and absorption. Because of the price difference between softwood and hardwood pulps, it makes sense to optimize the use of hardwood pulp, without compromising the required final properties of the tissue product and the efficiency of manufacturing. It is desirable to manufacture tissue paper with the required strength, bulk and softness, utilizing a furnish that requires as little energy as possible for dewatering and drying on the paper machine. ${ }^{3}$

Tissue paper has to be very flexible, with a high bulk and a smooth surface, and at the same time, it has to be sufficiently strong, with good absorption characteristics, and should not significantly lose strength when being embossed, laminated etc. To achieve this, it is generally accepted that the best fibres, both softwood and hardwood, must be slender, long and have a small wall thickness. Variability in pulp characteristics in terms of strength, bulk and softness is important and can influence the production efficiency and the quality of the end tissue paper product. $^{3}$

An important characteristic of tissue paper is liquid absorption, which is directly related to the softness and bulk. Paper is a product that easily interacts with water and its hydrophilic nature is due to cellulose fibres. Cellulose has hydroxyl groups that allow the formation of hydrogen bonds with water. This is the main reason why paper absorbs water. The water-absorption capacity of paper from cellulosic fibres often lies in the range between 2 and $10 \mathrm{~g} \mathrm{~g} \mathrm{~g}^{-1.5}$. An important aspect related to absorption is the porosity of the paper itself. Microscopic spaces between fibres make up a capillary geometry, through which water makes its way, saturating them.

Bulky papers can be obtained by using short and rigid eucalyptus fibres, especially at the initial levels of pulp stock refining. This property is closely associated with paper porosity. It interferes with numerous characteristics of paper. A higher bulk makes it possible to reduce the basis weight. This property is helpful in the production of tissue papers for facial or hygienic purposes, presenting high volume for the same paper weight or area.

Tissue papers demand the following quality parameters in relation to paper specifications and machine runnability: bulk, loosened paper structure, liquid absorption, hydrophilic paper surface, porosity, bulk and surface softness, drawings caused by dry creping and embossing, exact wet and dry paper strength, minimum tensile strength and elasticity modulus, capacity of the paper to retain pulp anatomical components (fines and vessels), exact wet web and dry strength to provide machine runnability, very fast drainage in the wet end and low fines content.

Tissue papers demand loose fibres in the paper structure. For this reason, fibre bonding is undesirable up to a certain extent. The fibres cannot collapse because this would result in a flatness of the fibres and paper surface, the paper has higher tensile strength, but all the tactile properties will be lost because of sheet compactibility. Pulp fines are also undesirable for two reasons: fibre bonding and building up in the paper machine white water system, which will be reflected in losses of drainability. ${ }^{6}$

The goal of this study was to compare the effect of bleached softwood and hardwood kraft pulps from different wood species on beatability, tensile properties, fibre characteristics, water absorption, softness and optical properties.

\section{EXPERIMENTAL}

\section{Materials}

Bleached softwood and hardwood kraft pulps

The following pulps were used for this study: bleached pine kraft pulp - Södra Black (pine), 
bleached pine/spruce kraft (mixture with spruce up to 45\%) - Botnia Nordic Pine + JNO (pine+spruce), bleached beech kraft pulp - Bukocel Slovakia (beech), bleached birch kraft pulp - Södra Gold (birch I), bleached birch kraft pulp - Botnia Nordic AKI (birch II), bleached eucalyptus kraft pulp - Pontevedra Spain (eucalyptus I) and bleached eucalyptus kraft pulp Celtejo Portugal (eucalyptus II).

\section{Methods \\ Pulp beating and handsheet preparation}

The bleached softwood and hardwood kraft pulps were beaten to 20,25 and $30^{\circ} \mathrm{SR}$ in a laboratory Jokro mill according to ISO 5264-3:1979. The handsheets $\left(60 \mathrm{~g} \mathrm{~m}^{-2}\right)$ from unbeaten and beaten pulps were prepared in a Rapid Köthen sheet former, according to the standard ISO 5269-2: 2004.

\section{Analyses}

The handsheets prepared from bleached softwood and hardwood kraft pulps were used for determining physical and mechanical properties. The tensile index, tensile energy absorption index and elongation at break were determined according to ISO 1924-2:2008 and wet tensile strength according to ISO 3781:2011. Fibre characteristics, such as fibre strength, fibre length and fibre bonding ability, expressed as FS number, L number and $\mathrm{B}$ number, were measured with a PULMAC Zero-Span 1000 instrument, according to ISO 15361:2000. Water absorption after 10 seconds immersion was determined according to ISO 5637:2015 and water absorption capacity - according to ISO 12625-8. Bulk softness was calculated from the bending stiffness determined at $15^{\circ}$ and $10 \mathrm{~mm}$ distance between the clamp and the knife-edge according to the TAPPI T 556 pm-95 method. Porosity $\varepsilon$ was calculated according to the equation given in the literature. ${ }^{7}$ The bulk was calculated from the apparent bulk density determined according to ISO 534:2011. The brightness was determined according to ISO 24701:2016. The optical surface variability was determined by simple analysis of the image obtained by the photoclinometric method with oblique surface illumination. ${ }^{8}$ Brightness was determined according to ISO 2470-1:2016, colour coordinate $b^{*}-$ according to ISO 5631-1:2015.

\section{RESULTS AND DISCUSSION \\ Beatability, tensile properties and fibre characteristics}

The properties of bleached kraft pulp from softwood and hardwood wood species used for the production of tissue paper were studied. The properties of two softwood kraft pulps prepared from pine and from the mixture of pine and spruce, five hardwood kraft pulps of two eucalyptus and two birch pulps from different manufacturers and one beech kraft pulp were compared.

The beatability of bleached softwood and hardwood kraft pulps was examined because the beating is an important operation in paper technology, which is associated with the consumption of electricity. Beating affects the dewatering performance of pulps and their properties. Figure 1 shows the evolution of drainage resistance (in ${ }^{\circ} \mathrm{SR}$ ) with beating time. The unbeaten bleached hardwood kraft pulps had higher drainage resistance from 1 to $3{ }^{\circ} \mathrm{SR}$, in comparison with the bleached softwood kraft pulps. After beating, the differences in the drainage resistance between the pulps increased. The beatability of the softwood kraft pulps was lower than that of the hardwood kraft pulps. At the drainage resistance achieved at $25{ }^{\circ} \mathrm{SR}$, the beating time of the bleached kraft pulps from different wood species increased in the following order: eucalyptus I (13.5 min) < beech $(14.5 \mathrm{~min})$ $<$ eucalyptus II $(15 \mathrm{~min})<$ birch II $(17 \mathrm{~min})<$ birch I $(20 \mathrm{~min})<$ pine $(23 \mathrm{~min})<$ pine+spruce (33 min). The results show that the bleached softwood kraft pulps require an average of twice longer beating time to achieve the same drainage resistance than the bleached hardwood kraft pulps.

Tensile properties, i.e. the scientific term for strength properties, include tensile strength, elongation, strain at break, Young's modulus, stiffness and elongation. Tensile strength is an important characteristic of tissue paper, which represents the maximum tensile force developed in a test specimen before rupture during the tensile test under the prescribed conditions. The tensile strength depends on fibre strength, fibre length and bonding ability. Figure 2 shows the evolution of the tensile indexes with the drainage resistance of the bleached softwood and hardwood kraft pulps. With increasing drainage resistance, the tensile indexes of all the pulps increased, mostly at $20^{\circ} \mathrm{SR}$. At this drainage resistance, the tensile indexes of the bleached kraft pulps from different wood species increased in the following order: eucalyptus I $\left(40 \mathrm{~N} \mathrm{~m} \mathrm{~g}^{-1}\right)<$ beech $\left(43 \mathrm{~N} \mathrm{~m} \mathrm{~g}^{-1}<\right.$ eucalyptus II $\left(55 \mathrm{~N} \mathrm{~m} \mathrm{~g}^{-1}\right)<$ birch II $\left(67 \mathrm{~N} \mathrm{~m} \mathrm{~g}^{-1}\right)<$ birch I $\left(70 \mathrm{~N} \mathrm{~m} \mathrm{~g}^{-1}\right)<$ pine $\left(77 \mathrm{~N} \mathrm{~m} \mathrm{~g}^{-1}\right)<$ pine+spruce $\left(80 \mathrm{~N} \mathrm{~m} \mathrm{~g}^{-1}\right)$. An analogous order for the tensile index of softwood and hardwood kraft pulps has also been achieved in our previous works. ${ }^{9,10}$

Wet tensile strength is an important feature for some types of products from tissue, such as 


\section{MÁRIA FIŠEROVÁ et al.}

towels. The cellulose fibre web of paper is mainly held together by hydrogen bonds. These are dependent on the physical contact between the fibres and can be broken by wetting of the fibres. In Figure 3, the dependences of wet tensile index on the drainage resistance of individual bleached kraft pulps are presented. The wet tensile indexes of the tested pulps beaten to $30{ }^{\circ} \mathrm{SR}$ increased 3-4 times. Prolonged beating times increased the wet tensile indexes of all the bleached pulps, most significantly to $20^{\circ} \mathrm{SR}$, similarly to the dry tensile indexes. The wet tensile indexes of the bleached kraft pulps from different wood species increased in the following order: eucalyptus I $(990 \mathrm{mN} \mathrm{m} \mathrm{g}$ $\left.{ }^{1}\right)<$ beech $\left(1050 \mathrm{mN} \mathrm{m} \mathrm{g}^{-1}\right)<$ eucalyptus II (1100 $\left.\mathrm{mN} \mathrm{m} \mathrm{g}{ }^{-1}\right)<$ birch II $\left(1170 \mathrm{mN} \mathrm{m} \mathrm{g}^{-1}\right)<$ birch I $\left(1230 \mathrm{mN} \mathrm{m} \mathrm{g} \mathrm{g}^{-1}\right)<$ pine $\left(1560 \mathrm{mN} \mathrm{m} \mathrm{g}^{-1}\right)<$ pine+spruce $\left(1630 \mathrm{mN} \mathrm{m} \mathrm{g}^{-1}\right)$. The tensile index of wetted handsheets from bleached kraft pulps was lower by about $98 \%$, compared to the dry tensile index (Fig. 2). The obtained low levels of wet tensile indexes of the bleached kraft pulps are in agreement with our previous results. ${ }^{4}$ The softwood kraft pulps had a significantly higher wet tensile index than the hardwood kraft pulps at the same drainage resistance. The wet tensile

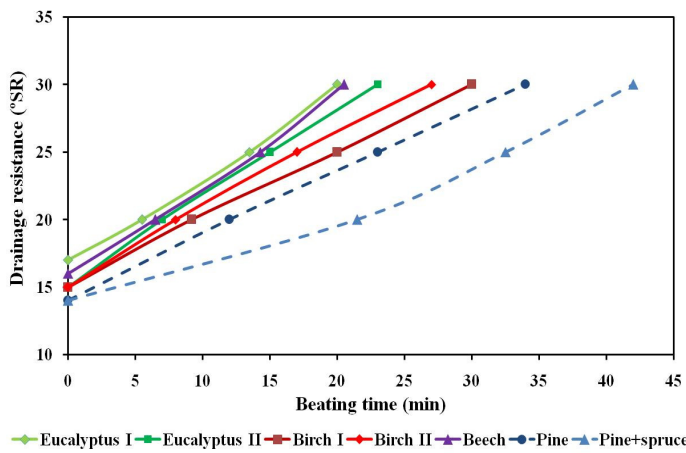

Figure 1: Drainage resistance vs. beating time of bleached softwood and hardwood kraft pulps

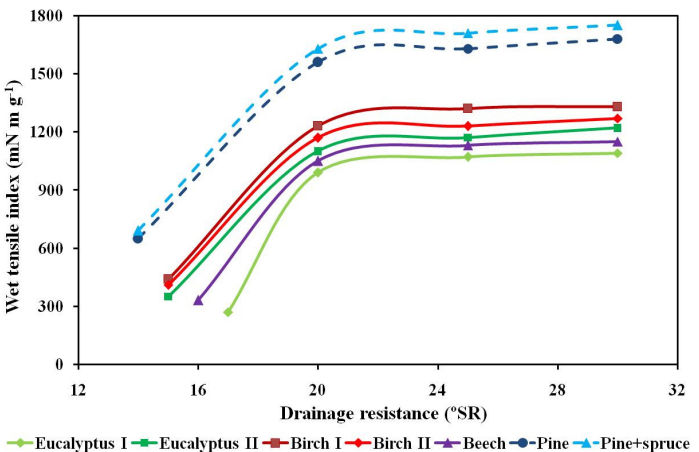

Figure 3: Wet tensile index vs. drainage resistance of bleached softwood and hardwood kraft pulps indexes of the bleached kraft pulps increased with the fibre length, which is consistent with the results reported in previous works. ${ }^{411}$ The weighted average fibre length of the pulps prepared from the mixture of pine and spruce was $2.8 \mathrm{~mm}$ and that of the pine pulp was $2.6 \mathrm{~mm}$, respectively. The weighted average fibre length of the birch pulps was $1.3 \mathrm{~mm}$ and $1.2 \mathrm{~mm}$, respectively. The eucalyptus pulps had the weighted average length of $1.1 \mathrm{~mm}$ and $1.0 \mathrm{~mm}$, similarly to the beech pulp.

The tensile energy absorption index as a function of drainage resistance of the bleached softwood and hardwood kraft pulps is shown in Figure 4. Tensile energy absorption represents the work done when a specimen is stressed to rupture in tension under prescribed conditions, as measured by the integral of the tensile strength over the range of tensile strain from zero to maximum strain. The tensile energy absorption is expressed as the energy per unit area of test specimen. The dependencies had an analogous trend to that obtained in the case of the tensile index (Fig. 2). At $20{ }^{\circ} \mathrm{SR}$, the tensile energy absorption indexes of the bleached kraft pulps were in the range from 550 to $1625 \mathrm{~mJ} \mathrm{~g}^{-1}$.

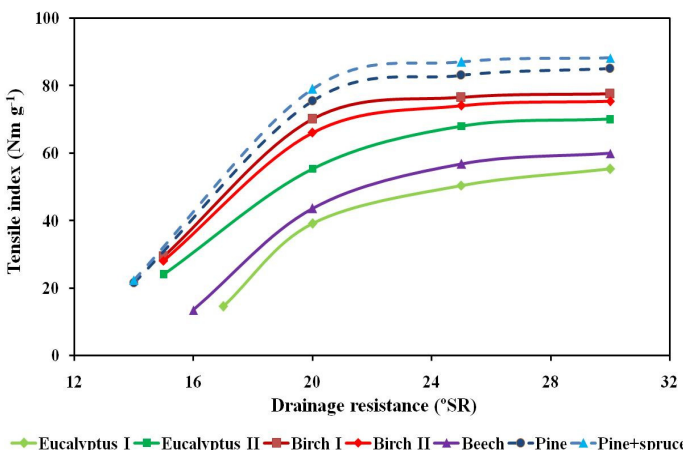

Figure 2: Tensile index $v s$. drainage resistance of bleached softwood and hardwood kraft pulps

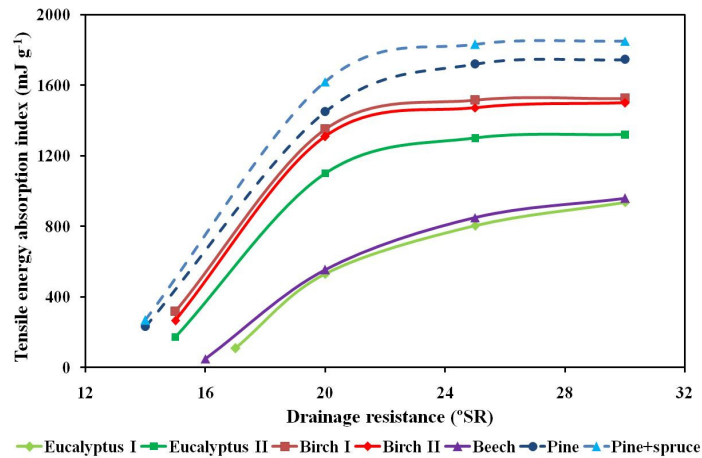

Figure 4: Tensile energy absorption index $v s$. drainage resistance of bleached softwood and hardwood kraft 


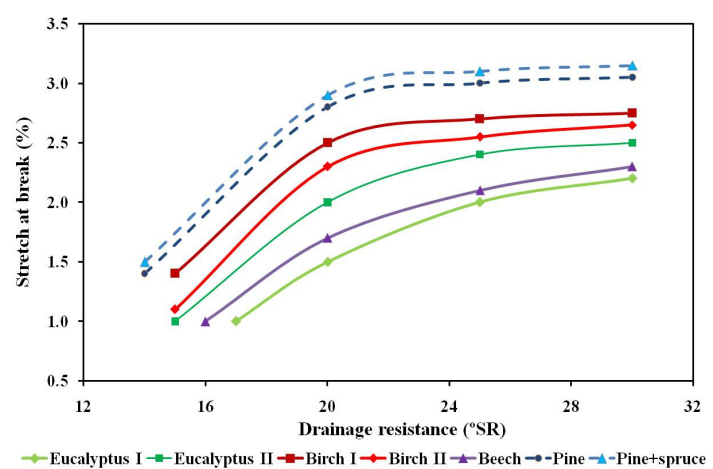

Figure 5: Elongation at break vs. drainage resistance of bleached softwood and hardwood kraft pulps

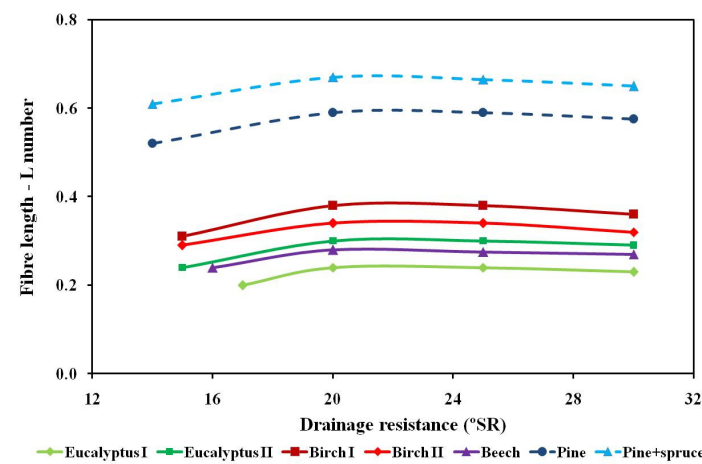

Figure 7: Fibre length (L number) vs. drainage resistance of bleached softwood and hardwood kraft pulps

In Figure 5, the elongation at break of the bleached softwood and hardwood kraft pulps at different drainage resistance is compared. Elongation represents the maximum tensile strain developed in the test specimen before the rupture in a tensile test carried to the rupture under prescribed conditions. The elongation at break of the bleached softwood and hardwood kraft pulps increased with the drainage resistance analogously to the tensile index (Fig. 2) and the tensile energy absorption index (Fig. 4). At the drainage resistance achieved at $20{ }^{\circ} \mathrm{SR}$, the elongation at break ranged from 1.5 to $2.9 \%$.

The strength properties of pulp handsheets determined by conventional methods are not suitable for their detailed specification because the fibre strength and the bonding between the fibres are not determined separately. The Pulmac Z-Span 1000 tester was used to determine Z-Span numbers: fibre strength (FS number), length (L number), and bonding (B number). FS number does not express the true fibre tensile strength, but is merely an indicator. L number is also only an indicator of average fibre length and $\mathrm{B}$ number is

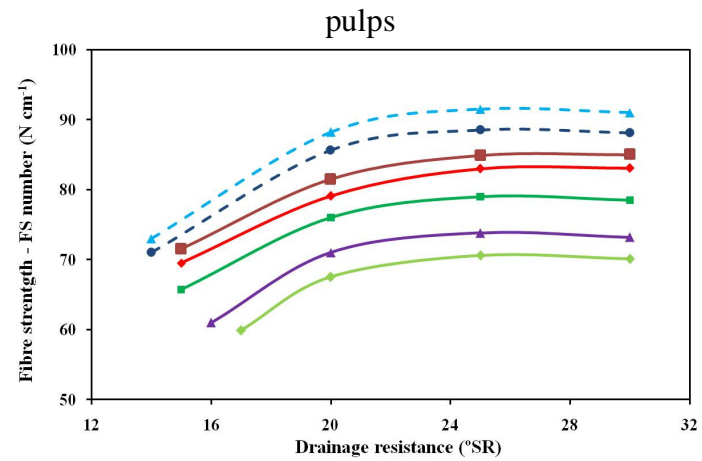

$\rightarrow$ Eucalyptus I $\rightarrow$-Eucalyptus II $\rightarrow$-Birch $\mathrm{I} \rightarrow-$ Birch II $\rightarrow$ Beech $\rightarrow$-Pine $\rightarrow-$-Pine+spruce

Figure 6: Fibre strength (FS number) vs. drainage resistance of bleached softwood and hardwood kraft pulps

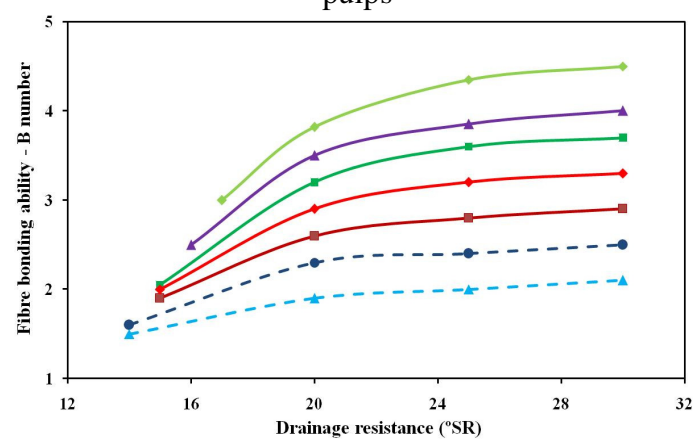

$\rightarrow$ Eucalyptus $\mathrm{I} \rightarrow$-Eucalyptus II $\rightarrow$-Birch $\mathrm{I} \rightarrow$ Birch $\mathrm{II} \rightarrow$ Beech $\rightarrow$-Pine $\rightarrow-$-Pine+spruce Figure 8: Fibre bonding ability (B number) vs. drainage resistance of bleached softwood and hardwood kraft pulps

an indicator of fibre bonding ability. In Figure 6, the dependencies of FS number on the drainage resistance of the bleached kraft pulps are presented. FS numbers of bleached kraft pulps increased to $25^{\circ} \mathrm{SR}$, and subsequently decreased with beating. This increasing FS number is explained by the fact that, by swelling and beating at low consistency, curled fibres are straightened, more fibres are clamped and thus FS number increases. ${ }^{12}$ At $20{ }^{\circ} \mathrm{SR}$, the FS numbers of the bleached kraft pulps from different wood species increased in the following order: eucalyptus I (67 $\left.\mathrm{N} \mathrm{cm}^{-1}\right)<$ beech $\left(69 \mathrm{~N} \mathrm{~cm}^{-1}<\right.$ eucalyptus II $(76 \mathrm{~N}$ $\left.\mathrm{cm}^{-1}\right)<$ birch II $\left(79 \mathrm{~N} \mathrm{~cm}^{-1}\right)<\operatorname{birch~I~}\left(82 \mathrm{~N} \mathrm{~cm}^{-1}\right)$ $<$ pine $\left(85 \mathrm{~N} \mathrm{~cm}^{-1}\right)<$ pine+spruce $\left(88 \mathrm{~N} \mathrm{~cm}^{-1}\right)$.

The influence of different wood species on the $\mathrm{L}$ number (fibre length) of bleached kraft pulps is presented in Figure 7. L numbers of the bleached sulphate pulps increased to $20{ }^{\circ} \mathrm{SR}$, and then slightly decreased with dewatering resistance. The increasing $\mathrm{L}$ number is related to the straightening of curled fibres upon swelling and beating. ${ }^{8}$ At 20 ${ }^{\circ} \mathrm{SR}$, the L numbers (fibre length) of the bleached kraft pulps from different wood species increased 
in the following order: eucalyptus I $(0.24)<$ beech $(0.28)<$ eucalyptus II $(0.30)<$ birch II $(0.34)<$ birch I $(0.38)<$ pine $(0.60)<$ pine+spruce (0.68). The order is the same as in the case of FS number (Fig. 6). The weighted average fibre length was four times greater than the L number determined by the Zero-Span tensile tester.

The dependencies of B number (fibre bonding ability) on the drainage resistance of bleached softwood and hardwood kraft pulps are shown in Figure 8. With increasing drainage resistance, the $\mathrm{B}$ number of the bleached kraft pulps increased. The bleached hardwood kraft pulps with lower tensile strength had, at the same drainage resistance, higher $\mathrm{B}$ number than the bleached softwood pulps with higher tensile strength. At 20 ${ }^{\circ} \mathrm{SR}$, the B number (fibre bonding ability) of the bleached kraft pulps from different wood species decreased in the following order: eucalyptus I (3.8) $>$ beech (3.5) > eucalyptus II (3.2) > birch II (2.9) $>$ birch I (2.6) > pine (2.3) > pine+spruce (1.9). The order of the pulps is the opposite to that for the FS number (Fig. 6) and L number (Fig. 7).

The dependencies of FS, L and B numbers on the drainage resistance of the evaluated bleached softwood and hardwood kraft pulps from different wood species were analogous to those found for unbleached and bleached softwood and hardwood kraft pulps..$^{9,10,13}$

At the same drainage resistance, the softwood kraft pulps had higher fibre strength (FS number) and fibre length ( $\mathrm{L}$ number) than those of hardwood kraft pulps, which is consistent with the higher tensile index (Fig. 3), wet tensile index (Fig. 4), tensile energy absorption index (Fig. 4) and elongation at break (Fig. 5). It follows that the fibre strength and fibre length had a significant effect on the tensile strength of the bleached softwood and hardwood kraft pulps from different wood species.

\section{Functional properties of tissue paper}

The main property of tissue paper is absorption, which is directly related to the softness and bulk, although not always in the same way. An important aspect of water absorption is the porosity of the paper itself. The water passes through the microscopic spaces between the fibres and saturates them. Water absorption of the handsheets prepared from the bleached kraft pulps was determined as water absorption after 10 second immersion (Fig. 9) and water absorption capacity (Fig. 10). The unbeaten pulps had the highest water absorption. Pulp beating reduces water absorption, as confirmed by the results in Figures 9 and 10. At the same drainage resistance, the bleached kraft pulps from eucalyptus and beech wood had higher water absorption than the pulps from birch and softwood.

In Figure 11, the dependencies of porosity $\varepsilon$ on the drainage resistance of bleached softwood and hardwood kraft pulps are presented. With increasing the drainage resistance, the porosity $\varepsilon$ decreased, most significantly at $20{ }^{\circ} \mathrm{SR}$. Eucalyptus and beech pulps had higher porosity $\varepsilon$ than softwood pulps. Birch kraft pulps have the lowest porosity $\varepsilon$. The dependencies of porosity $\varepsilon$ on the drainage resistance of the individual pulp species had an analogous course as for the water absorption (Figs. 9 and 10). The results confirmed that the water absorption of the handsheets from bleached kraft pulps depends on their porosity.

Bulk is closely associated with paper porosity. A high bulk is important in the production of tissue papers for facial or hygienic purposes. The bulk of bleached softwood and hardwood kraft pulps decreased with increasing drainage resistance (Fig. 12). The dependencies for individual bleached kraft pulps are similar to those obtained in the case of water absorption (Figs. 9 and 10), because bulk and water absorption depend on porosity. At the same drainage resistance, eucalyptus and beech bleached kraft pulps had higher bulk than the pulps from birch and softwood.

The feeling of softness, or tactile softness, is one of the properties mostly desired in the tissue grade papers. Softness is a complex phenomenon, which incorporates many aspects of human interaction with the tissue product. It is believed to be influenced by both bulk and surface softness. The perception of bulk softness is discerned by gentle crumpling or folding of the tissue, and is inversely related to flexural rigidity or bending stiffness. Bending stiffness was used to determine the bulk softness of the bleached softwood and hardwood kraft pulps (Fig. 13). The unbleached pulps had the highest bulk softness, which reached the lowest value after beating to 20 ${ }^{\circ} \mathrm{SR}$ and then slightly increased with beating. The bleached birch kraft pulps had higher bulk softness than the pulps from eucalyptus and beech wood. The bleached softwood kraft pulps had the lowest bulk softness.

The optical surface variability of the bleached kraft pulps was determined by the simple analysis 
of the image using the photoclinometric method, which was used in the evaluation the surface of tissue paper products. $^{8}$ The dependencies of optical surface variability on the drainage resistance of bleached softwood and hardwood kraft pulps are shown in Figure 14. Pulp beating reduces optical surface variability. The

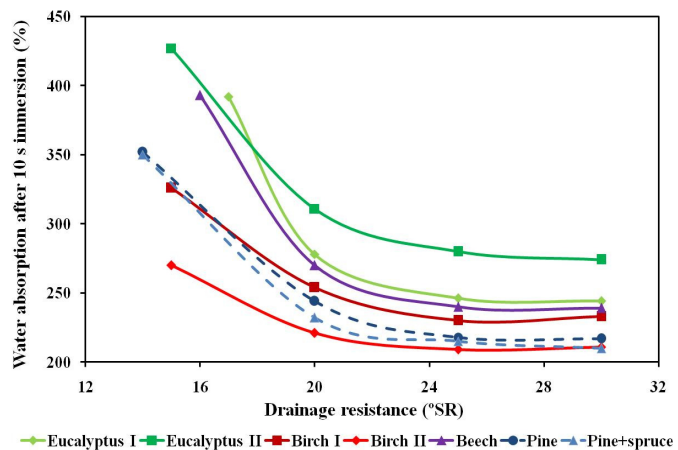

Figure 9: Water absorption after 10 seconds immersion vs. drainage resistance of bleached softwood and hardwood kraft pulps

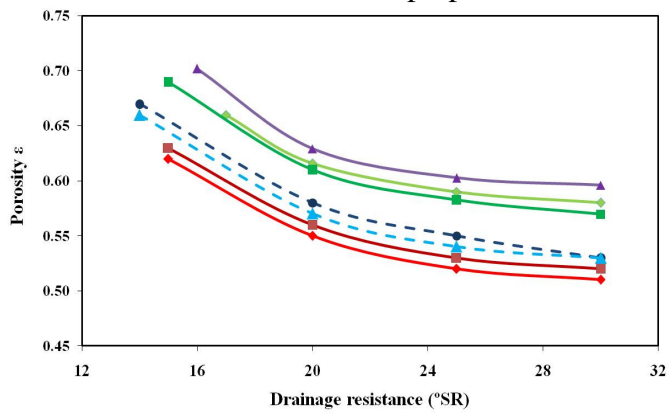

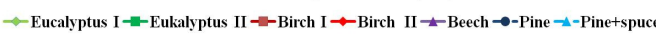

Figure 11: Porosity \& vs. drainage resistance of bleached softwood and hardwood kraft pulps

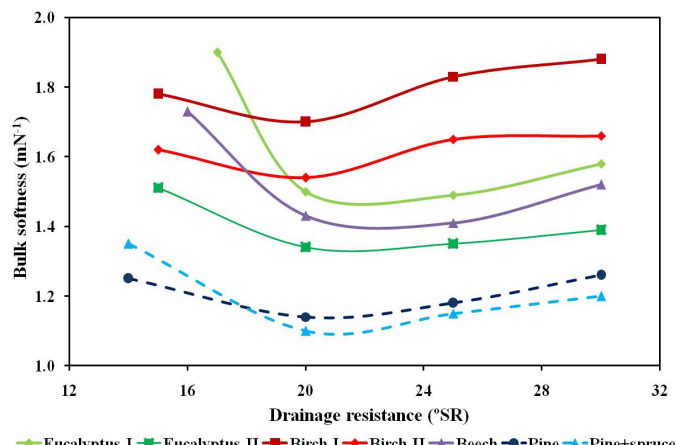

Figure 13: Bulk softness vs. drainage resistance of bleached softwood and hardwood kraft pulps handsheets made from the bleached kraft pulps made up from the mixture of pine and spruce had the highest optical surface variability and those from the pine pulp - the lowest bulk softness (Fig. 13). On the other hand, the handsheets from the bleached birch kraft pulps had the lowest optical surface variability, but the highest bulk softness.

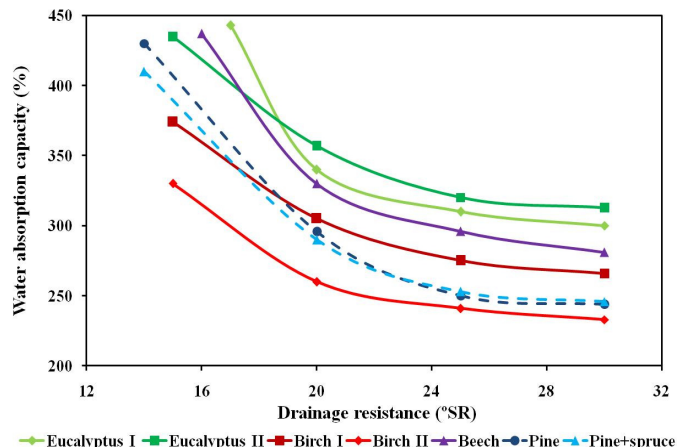

Figure 10: Water absorption capacity $v s$. drainage resistance of bleached softwood and hardwood kraft

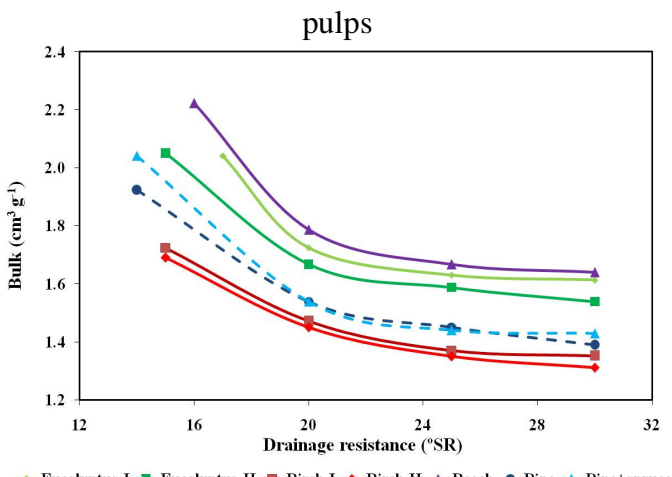

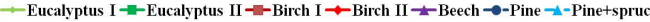
Figure 12: Bulk vs. drainage resistance of bleached softwood and hardwood kraft pulps

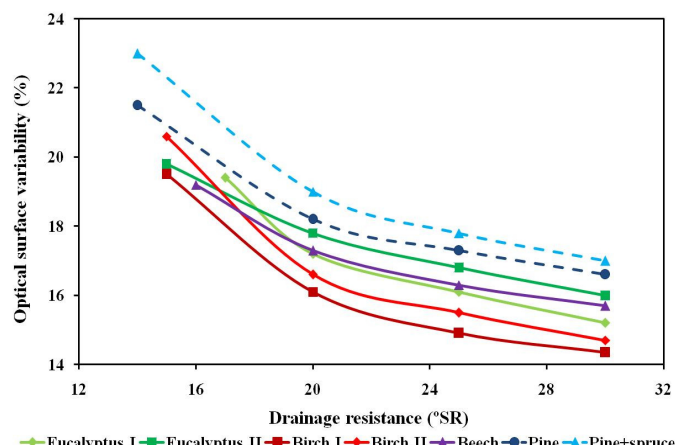

Figure 14: Optical surface variability $v s$. drainage resistance of bleached softwood and hardwood kraft pulps 


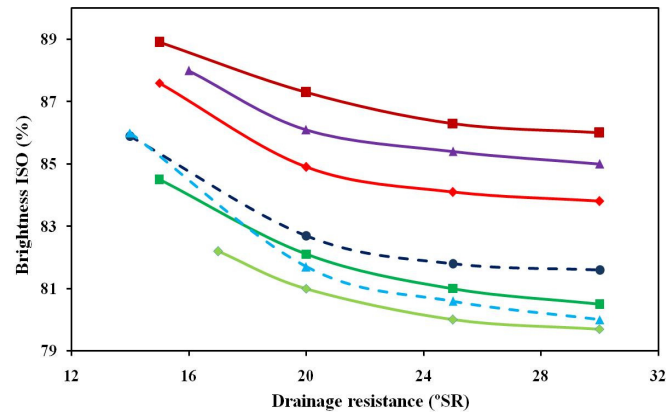

$\rightarrow$ Eucalyptus $\mathrm{I}-$-Eucalyptus $\mathrm{II} \rightarrow$-Birch $\mathrm{I} \rightarrow$-Birch II $\rightarrow$-Bech $\rightarrow$-Pine $\rightarrow$-Pine+spruce Figure 15: Brightness vs. drainage resistance of bleached softwood and hardwood kraft pulps

In Figure 15, the effect of laboratory beating on the brightness of the bleached softwood and hardwood kraft pulps is presented. The brightness of unbeaten pulps ranged from 82.2 to $88.9 \%$ ISO. At $30{ }^{\circ} \mathrm{SR}$, the brightness of the pulps decreased by about 1.5 to $2.0 \%$ ISO. The bleached birch and beech kraft pulps had the highest brightness, while the eucalyptus and softwood pulps had lower brightness.

Paper can reflect or absorb light of certain wavelengths. The CIELAB system allows expressing the colour of paper and the colour deviation between two papers, as closely as possible, to respond to visual perception. The colour is defined by the coordinates $\mathrm{L}^{*}, \mathrm{a}^{*}$ and $\mathrm{b}^{*}$, where the positive value of coordinate $\mathrm{b}^{*}$ represents yellow colour and the negative value blue colour. The value of coordinate $b^{*}$ increased with drainage resistance of the bleached kraft pulps (Fig. 16), in contrast to the brightness (Fig. 15). The eucalyptus and softwood kraft pulps had higher coordinate $\mathrm{b}^{*}$ values, while birch and beech kraft pulps had lower coordinate $b^{*}$ values.

\section{CONCLUSION}

Fibre is a major contributor to the overall cost of tissue paper manufacturing, typically accounting for $50 \%$ of the total cost of the finished product. Furthermore, fibre quality is a key contributor to tissue quality, influencing such attributes as softness, water absorption and strength. The highest quality tissues incorporate some virgin pulps, usually a combination of long softwood fibre and short hardwood fibre kraft pulps. The type of pulp, the beating conditions and the furnish composition influence paper properties and make it possible to fulfil various requirements for tissue paper products.

Softwood kraft pulps contribute to strength, which is needed during production and

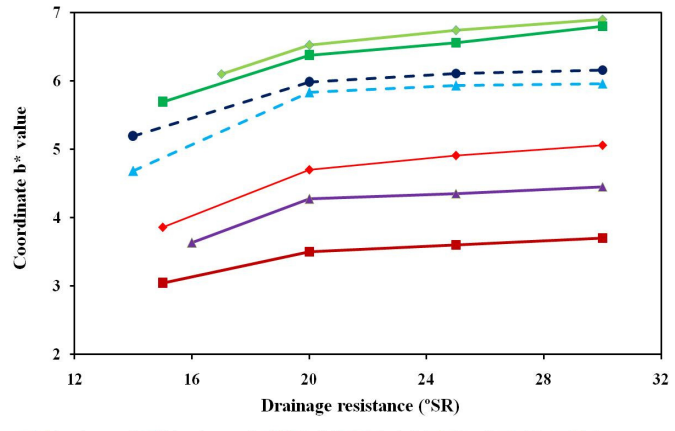

$\rightarrow$ Eucalyptus I-E-Eucalyptus II - -Birch $\mathrm{I} \rightarrow$-Birch II - -Beech $\rightarrow$-Pine -1 -Pine+spruce

Figure 16: Coordinate $\mathrm{b}^{*}$ value vs. drainage resistance of bleached softwood and hardwood kraft pulps

conversion. A mixture of bleached softwood kraft pulp and bleached eucalyptus kraft pulp or beech kraft pulp gives a good combination of water absorption and wet tensile strength, which is required for paper towels.

Bleached hardwood kraft pulps are used to make tissue paper for cosmetic towels and napkins, which require high bulk softness and absorbency. The birch kraft pulps are suitable for production of tissue paper, if higher strength and bulk softness are required. For tissue products, with high water absorption and low wet tensile strength, such as toilet paper, bleached eucalyptus kraft pulp and beech kraft pulp are suitable.

The latest tissue making technologies involve structuring of tissue paper, in an effort to generate bulk, softness and absorption. This approach can produce the highest quality tissue products, with a high bulk over basis weight, combined with high softness.

ACKNOWLEDGEMENTS: This work was supported by the Slovak Research and Development Agency under contract No. APVV16-0428.

\section{REFERENCES}

1 O. Kimari, "Papermaking Science and Technology", Fapet Oy, Helsinki, Finland, Book 18, Chapter 3, 2000, pp. 73-93

2 G. V. Laivins and A. M. Scallan, J. Pulp Pap. Sci., 22, 178 (1996)

P. Watson, Tissue World Magazine, May/June (2014), http://www.tissueworldmagazine.com/

4 J. Gigac and M. Fišerová, Tappi J., 7, 27 (2008), https://www.tappi.org/publications-standards/tappijournal/

5 P. D. Beuther, M. W. Veith and K. J. Zwick, J. Eng. Fibers Fabrics, 5, 1 (2010), http://www.jeffjournal.org/ 

C. Foelkel, Eucalyptus Online Book \& Newsletter, No. 8, March 2007, http://www.eucalyptus.com.br/capitulos/ENG08.pdf

7 E. Daub, H. Sindel and L. Göttsching, Das Papier, 40, 188 (1986).

8 J. Gigac, M. Fišerová, M. Stankovská and M. Maholányiová, "Prediction of water-absorption capacity and surface softness of hygienic paper products using photoclinometry". O Papel (in press), http://www.revistaopapel.org.br/

9 M. Fišerová, J. Gigac and J. Balberčák, Cellulose Chem. Technol., 44, $249 \quad$ (2010), http://www.cellulosechemtechnol.ro/pdf/CCT44,78(2010)/p.249-253.pdf
10 M. Fišerová and J. Gigac, Cellulose Chem. Technol., $\quad 45, \quad 627 \quad$ (2011), http://www.cellulosechemtechnol.ro/pdf/CCT45,910(2011)/p.627-631.pdf

11 R. S. Seth, M. C. Barbe, J. C. R. Williams and D. H. Page, Tappi J., 65, 135 (1982), https://www.tappi.org/publications-standards/tappijournal/

12 R. S. Seth and B. K. Chan, Tappi J., 82, 115 (1999), https://www.tappi.org/publicationsstandards/tappi-journal/

13 M. Fišerová, J. Gigac and Š. Boháček, Wood Res., 55, 63 (2010), 